\title{
Kavak Tepecik Tümülüsü Üzerine Gözlemler ${ }^{1}$
}

\author{
Observations on Kavak Tepecik Tumulus
}

\author{
Davut YíĞiTPAŞA ${ }^{2}$ \\ Akın TEMÜR ${ }^{3}$
}

\author{
Araştırma Makalesi / Research Article \\ Geliş Tarihi / Received: 14. 04. 2021 \\ Kabul Tarihi / Accepted: 14. 05. 2021 \\ Doi: 10.48146/odusobiad.916029
}

\begin{abstract}
Atıf / Citation: Yiğitpașa, D., ve Temür, A., (2021). "Kavak Tepecik Tümülüsü Üzerine Gözlemler" ODUSOBIAD, 11(2), 451-466, doi: 10.48146/odusobiad.916029
\end{abstract}

\begin{abstract}
Öz
Antikçağın mezar anıtlarından olan tümülüsler, gerek içindeki mezar odasının mimarisi ve gerekse mezar sahibine sunulan hediyeleriyle birlikte yapıldığı dönemin ve ait olduğu uygarlığın mimarisini ve sosyo ekonomik yapısını anlamamızı sağlayan önemli arkeolojik yapılardır. İçerisinde mezar sahiplerine sunulan değerli ölü armağanlarından dolayı, yapıldığı dönemden itibaren definecilerin gözde mekanlarına dönüșen bu yapıları, sağlam olarak ele geçirmek oldukça güçtür. Yüzey araștırmalarında tespiti yapılan tümülüslerin hepsinin kazısını yapmak mümkün değildir. Birçoğuna da ancak soyulduktan sonra müdahale edilebilmektedir. Çalıșmaya konu olan Tepecik Tümülüsü de bunlardan biridir. Her ne kadar soyulmuș olsa da mimari formunu büyük ölçüde koruyabilmiştir. Samsun ve çevresinde çok sayıda tümülüsün bulunduğu düşünüldüğünde kazısı yapılabilen Tümülüs sayısı bir elin parmaklarını geçmemektedir. Bu kapsamda Tepecik Tümülüsü gerek mezar odasının mimari formu ve gerekse buluntularıyla bölgenin ölü gömme adetleri ve teknolojisi konusunda önemli bilgiler sunmaktadır. Hellenistik tümülüsleri; bir mezar odası ve ön oda olmak üzere iki bölümden oluşmaktadır ve bu odalara bir dromosla girilmektedir. Mezar odalarının üzeri kesme taştan yapılmış, beșik tonoz örtüyle kaplıdır. Dromos girişleri genelde doğu yönlüdür. Tümülüste bulunan seramikler düzleştirilmiş ağız kenarlı derin kaseler, kısa boyunlu çömlekler, monokrom ve polikrom boya bezemeli amorflardan oluşmaktadır. İnce çeperli, yüksek bir teknik ve artistik işçiliği olan "Nitelikli Mal" olarak adlandırabileceğimiz karakteristik özellikli parçalar üzerindeki pembe, krem, açık krem, kirli beyaz ve açık, pembemsi kahve hamurlu, hamurunun renginde astarlı ve iyi açkılıdırlar. Bu kapların bir kısmı bezemeli bir kısmı ise bezemesizdir. Çanak-çömlek parçaları ile mimari birlikte bir bütün olarak değerlendirildiğinde, mezar yapısının MÖ 2. yüzyılda inşa edildiği düşünülmektedir.
\end{abstract}

Anahtar Kelimeler: Kavak Tepecik Tümülüsü, Oda Mezar, Karadeniz Arkeolojisi, Amisos, Hellenistik

\begin{abstract}
Tumuli, one of the grave monuments of antiquity, are important archaeological artifacts that enable us to understand the architecture and socio-economic structure of the period and civilization in which it was built, together with the architecture of the tomb chamber and the gifts presented to the tomb owner. It is very difficult to seize these structures, which have become favorite places of treasure hunters since the time they were built, due to the valuable gifts, presented to the grave owner It is not possible to excavate all of the tumuli detected in the survey Many of them can only be intervened after they are robbed. Tepecik Tumulus, which is the subject of the study, is one of them. Although it has been robbed, it has been able to preserve largely managed to maintain its architectural form. Considering that there are many tumuli in Samsun and its surroundings, the number of tumuli that can be excavated does not exceed the fingers of one hand. In this context, Tepecik Tumulus provides important information about the burial customs and technology of the region with both the architectural form of the burial chamber and the finding Hellenistic tumuli; it consists of two parts, a tomb chamber and an anterior chamber, and these rooms are entered by a dromo The grave chambers are made of cutting stone and covered with a barrel vault cover. Dromos entrances are generally east oriented. The ceramics found in the tumulus consist of flattened rimmed deep
\end{abstract}

\footnotetext{
${ }^{1}$ Bilgi, belge, fotoğraf ve diğer dokümanlar üzerinde çalışma ve yayın izni veren Samsun Müzesi Müdür V. Uğur Terzioğlu Uzman Emine Yılmaz'a teșekkür ederiz.

2 Sorumlu Yazar, Doç. Dr. Ondokuz Mayıs Üniversitesi, Fen-Edebiyat Fakültesi, Arkeoloji Bölümü, Samsun e-mail: davut.yigitpasa@omu.edu.tr ORCID No: 0000-0001-8821-5628

${ }^{3}$ Doç. Dr. Ondokuz Mayıs Üniversitesi, Fen-Edebiyat Fakültesi, Arkeoloji Bölümü, Samsun. e-mail: akintemur@yahoo.com ORCID No: 0000-0001-9777-5256
} 
bowls, short necked jars, monochrome and polychrome painted amorph Fine-walled, high technical and artistic workmanship, the characteristic pieces that we can call "Fine Ware" are pink, cream, light cream, off-white and light, pinkish brown paste, lined in the color of the paste and well burnished. Some of these pottery are decorated and some are undecorated. Considering the pottery and the architecture as a whole, it is thought that the tomb structure was built in the 2nd century $B C$.

Keywords: Kavak Tepecik Tumulus, Chamber Tomb, Black Sea Archeology, Amisos, Hellenistic

\section{Giriş}

Arkeoloji literatüründe kral, kraliçe veya soylu kişiler için yapılmış, içte bir mezar odası ve üzerine yığılan taş ve topraklardan oluşan yapay tepeciklere tümülüs adı verilmektedir (Tekçam, 2007: 236; Yücel, 2017: 163). Dış görünüşü çok değişmemekle birlikte kullanıldığı dönem ve uygarlığa göre mezar odası farklı malzeme ve şekillerde olabilen tümülüslere, ceset ile birlikte muhtelif eşya ve ölü hediyelerinin konması onları daha da önemli kılmaktadır (Ökse, 2005, 1). Tümülüsler, gerek dolgu katmanında gerekse mezar odalarında birçok yapısal unsura sahiptirler. Bunlar; krepis, dromos, ön avlu, sundurma, ön oda, asıl mezar odası ve üst örtü sisteminden oluşmaktadır (Yücel, 2017, 161). Friglerle Anadolu'ya geldiği kabul edilen tümülüslerin (Metin, 2014, 146), Friglerin (Phrygler) bir Trak kavmi olduğu tezi üzerinden değerlendirildiğinde (Mansel, 1995, 87-92) bu mezar anıtlarının kökenleri Trakya ${ }^{4}$ (Thrakia) Doğu Avrupa ve Makedonya'da aranmaktadır. ${ }^{5}$ Orta Tunç Çă̆ı'nda soylular için tümülüs mezarların kullanıldı̆̆ı bilinmektedir. Balkan tümülüslerinin Anadolu'daki Frig tümülüsleri ile benzeyen tarafları olmakla birlikte, mimari açıdan ayrılıkları da vardır. Balkan tümülüslerinde ahşap mezar odası yerine, etrafı taşlarla çevrilmiş üzeri levha taşlarla örtülü, dikdörtgen formlu sandukalar kullanılmıştır. Birden fazla gömünün yapıldığı bu tümülüsler, iç dizaynda kurgan düzenlemesine sahip bu mezarların sahipleri, Transkafkasya kökenli olmalıdır. Güney Rusya ve sonrasında İskitlerle (Tsetskhladze, 2005, 37-65; Tsetskhladze, 2020, 55-92) bağlantılı olarak Orta Asya'da sıkça karş̧laşılan kurganlar, tümülüs mezar geleneğinin öncüleri olup, buradan Anadolu'ya ve Balkanlar'a geçmiş olmalıdır. Ancak Anadolu'ya tam olarak ne şekilde girdikleri belirsizliğini korumaktadır (Young, 1981, 264).

İlk olarak MÖ 8. yüzyılın ortalarında Orta Anadolu'da ortaya çıkan bu mezar yapısının (Öztekin, 2006: 25; Avşar, 2016: 5), MÖ 7. yüzyılın sonlarında Lidyalılar Dönemi'nde Batı Anadolu'da, Greko-Pers Dönemi'nde Anadolu'nun farklı bölgelerinde, Hellenistik Döneme gelindiğinde ise, çok geniş bir coğrafyaya yayıldığı görülmektedir (Mansel, 1974, 181-189; Sevinç-Treister, 2003, 215-260; Şahin, 2009, 25-38; Ylldırım, 2010, 149-178; 2018, 1295-1319; Mert, Şahin, Altın, 2018, 203-254). Bu tümülüslere genel olarak bakıldığında; Friglerde; ahşaptan yapılmış, tek odalı dışa kapalı bir mezar odası görülürken (Erdoğan, 2007, 10-47; Avşar, 2016, 10-24), Lidya Tümülüslerinde bir veya üç odalı, dromoslu (koridor), taş duvarla çevirili bir mezar yapısı izlenir (Dinç, 1993, 108-283; Avşar, 2016, 25-37). Greko-Pers tümülüsleri ise, dromos, ön oda ve mezar odasından oluşan bir mezar yapısıyla karşımıza çıkar (Avşar, 2016, 65-82). Hellenistik dönemde bu mezar yapısına sunu odasının da eklendiği görülür (Kutsal Oda) (Öztekin, 2006, 25).

Genelde Karadeniz Bölgesi'ne özelde ise Samsun'daki tümülüslere baktığımızda; tümülüsler ve ölü gömme adetleriyle ilgili olarak, yapılan çalışmaların yeterli düzeyde olmadığı görülmektedir. Samsun ve ilçelerinde yüzü aşkın tümülüs tescillenmiş olmasına karşın çok azında kazı yapılabilmiștir. Bu tümülüslerin çoğu tahrip edilerek soyulmuş ve buluntuları çeşitli müzeler ile özel koleksiyonlara dağılmıştır (Atasoy, 1997, 51-52). Bölgede bulunan büyük tümülüslerden çok azında kazı yapılmıştır. Bu kazıların birçoğu ise defineciler tarafından yapılan tahribat sonrasında kurtarma kazısı şeklinde gerçekleștirilmiștir. Bu Tümülüslerden ilki Havza ilçesinde bulunan Lerdüge Tümülüsü’dür. Söz konusu tümülüs Lerdüge Köyü'nde tespit edilen beș tümülüsten biridir. “4 Numaralı Tümülüs” olarak kayıtlara geçmiş olan tümülüs; $16 \mathrm{~m}$ yüksekliğinde, $35 \mathrm{~m}$ çapında olup, dromos ve mezar odasından oluşmaktadır. Dromosun mezar odasına yakın kısmı ile mezar odası kesme taş tonoz örtüsüne sahiptir (Akok, 1948, 835-853). İkinci bir Tümülüs Bafra ilçesinde bulunan İkiztepe Tümülüsü’dür. İkiztepe Höyügü'nde yürütülen kazılar sırasında tespit edilen Tümülüs; dromos, tonoz örtülü ön oda ve bir mezar odasından oluşmaktadır (Alkım-Alkım-Bilgi, 1988; Bilgi, 1999, 27-54; Bilgi vd., 2005,

${ }^{4}$ Trakya'da çoğu Hellenistik Dönem'e tarihlenen 15.000 mezar tespit edilmiștir. Hoddinot, 1975: 28; Hoddinot, 1981: 119126. Bölgede bulunan Tümülüsler ve buluntuları için bkz. Venedikov-Gerassimov, 1975: 53-63; Onurkan, 1988; Tsetskhladze, 2005: 57-65; Yıldırım, 2008: 64-223.

${ }^{5}$ Yunan ve Makedon taş ustalarının Trakya'da beşik tonozlu mezarların yapımında çalışmış olabileceği ifade edilmektedir. Bordman, 1994: 191. 
392). Benzer özelliklere sahip iki Tümülüs İlkadım ilçesinde, Amisos kentinin nekropol alanı içinde bulunmaktadır. MÖ 3-2. yüzyıla tarihlenen ve Baruthane Tümülüsleri olarak adlandırılan tümülüslerden güneydeki $15 \mathrm{~m}$. yüksekliğinde $40 \mathrm{~m}$. çapında ve konglomera tabakasının oyulması ile oluşturulmuş iki odalı bir mezar yapısına sahipken, kuzeydeki $8 \mathrm{~m}$. yüksekliğinde, $30 \mathrm{~m}$. çapında olup, iç içe oluşturulmuş üç odadan oluşmaktadır (Atasoy-Endoğru-Dönmez, 2005, 153-165). Kazısı yapılan bir diğer tümülüs Canik ilçesinde bulunan Dondortepe Tümülüsü'dür. Baruthane Tümülüsleri'nde olduğu gibi konglomera tabakasının oyulmasıyla oluşturulan kuzeydoğu ve batıya bakan iki dromos, ön oda ve iki yanında defin nişi bulunan mezar odasından oluşmaktadır (Ünan, 2009, 1-28). MÖ 3. yüzyıla tarihlenen tümülüsün ön odasına, MS 1. yüzyılda batı yönüne ikinci bir dromos eklenerek mezar odasının tekrar kullanım gördüğü düşünülmektedir (Ünan, 2009, 7). Yine aynı ilçede bulunan Toptepe Tümülüsü de benzer şekilde dromoslu mezar odası ve tonozlu üst örtüsüyle aynı geleneği devam ettirmektedir. ${ }^{6}$ Benzer bir tümülüs Atakent ilçesinde tespit edilmiştir. Samsun Müze Müdürlüğü tarafından temizlik çalışması yapılan tümülüs, dromoslu bir mezar odası ve beşik tonozlu üst örtüsünün inşa tekniğiyle Dondortepe Tümülüsü ile çok benzer özellikler gösterirken, dromosunun ana zemin üzerine, işlenmiş taşlarla oluşturulmuş olması bakımından, tortul kayaca oyularak yapılan Dondortepe Tümülüsü'nden ayrılmaktadır (Ünan, 2013, 14). Samsun'un Vezirköprü ilçesinde de çok sayıda tümülüs tespit edilmiştir (Temür-Yiğitpaşa, 2020a, 619-654; 2020b, 2865-2894). Ancak bu tümülüslerden yalnızca Ahmetbaba Tümülüs'nde kazı çalışmaları yapılmış olup, oda kaçak kazı ihbarı sonrası gerçekleştirilmiştir. Dromoslu olarak yapılan tümülüsün mezar odası büyük ölçüde tahrip edildiği için planı hakkında yeterli bir bilgiye ulaşılmamaktadır. Ancak taş işçiliği ve yapı özelliklerinden Hellenistik Döneme tarihlenmiştir. ${ }^{7}$

\section{Tepecik Tümülüsü}

Çalışmaya konu olan Tepecik Tümülüsü8 Samsun İlinin Kavak İlçesine yaklaşık $2 \mathrm{~km}$. mesafede, Kavak-Tepecik Mahallesi asfaltının kuzey yönünde yer almaktadır (Görsel 1). Yaklaşık 8-10 m. yüksekliğinde ve 20-30 m. çapındaki tümülüsün düz bir arazi üzerine konumlandığı çevresindeki arazi topografyasından anlaşılmaktadır ${ }^{9}$ (Görsel 2). Zamanla çevresi ve üzerinde oluşan bitki dokusu sebebiyle gözden uzak olmuş ve çok sayıda kaçak kazıya maruz kalmıştır. ${ }^{10}$ Tümülüs üzerinde yapılan ilk incelemelerde; tümülüsün dış toprak dolgusunda yasa dışı kazılarla derin çukurların oluştuğu ve mezar odasının tonozlu tavan örtüsünün tahrip edilerek çökertildiği tespit edilmiştir. Tümülüs mezar odasının herhangi bir soygun girişiminin önüne geçmek amacıyla tam tepe merkezinde olmayıp merkezden kuzey-doğu yönünde kaydırıldığı görülmektedir. Kurşun kenetlerle ve demir bağlantı çubuklarıyla birleştirilen kesme blok taşlardan inşa edilen Tümülüs, dromos, ön oda, mezar odası ve sunu odasından oluşmaktadır. ${ }^{11}$ Tepecik Tümülüsü'nde gerçekleştirilen çalışmalarda ele geçen çanak-çömlek parçaları ile mimari birlikte bir bütün olarak değerlendirildiğinde, mezar yapısının MÖ 2. yüzyılda inşa edildiği düşünülmektedir. Tümülüs içinde farklı dönemlere ait herhangi bir buluntuya rastlanmamış olması, ikinci bir kullanım geçirmediğini göstermesi açısından oldukça önemlidir. Bu noktada Tepecik Tümülüsü'nün gerek mimari formu ve gerekse buluntularıyla, bölgenin ölü gömme adetleri ve teknolojisi konusunda literatüre oldukça önemli bilgiler sunacağı aşikârdır.

Çalışmalara ilk olarak; durum değerlendirilmesi yapmak için tümülüsün kuzeydoğu eteğinden, yasa dışı kazılarla açılmış olup güney yönde ilerleyen ve tepe üst seviyesinden yaklaşık $6 \mathrm{~m}$. derinlikte

\footnotetext{
${ }^{6}$ Söz konusu tümülüste Samsun Müze Müdürlüğü tarafından bir kazı gerçekleştirilmiştir. Ancak kazıyla ilgili herhangi bir yayın yapılmamıștır.

7 Vezirköprü Asliye Ceza Mahkemesi Hakimliği 2017/129 Esas No'lu davada bilirkiş̧ilik yapılmış, tümülüs yerinde incelenmiş ve müze raporuna dava dosyasından ulașilmıștır.

${ }^{8}$ Söz konusu tümülüste Samsun Müze Müdürü Muhsin Endoğru Başkanlığında, Restoratör İlkay İvgin, Arkeolog Emine Yllmaz, Arkeoloji ve Sanat Tarihi Bölümü öğrencileri ile işçilerden oluşan bir ekiple 06/08/2015-18/09/2015 tarihleri arasında bir kurtarma kazısı gerçekleştirilmiştir. Samsun Müze Müdürlügü’nün 11/04/2018 Tarih ve 315728 Sayılı izni ile gerçekleştirilen bu çalışmada, arşivdeki bilgi, belge, çizim, rapor ve fotoğrafları kullanmamıza izin veren Müze Müdürü Muhsin Endoğru ve Emine Yllmaz'a ve projeyi destekleyen Ondokuz Mayıs Üniversitesi Proje Yönetim Ofisi'ne (PYO.FEN.1901.17.009) teșekkürü bir borç biliriz.

9 Tümülüsün batısında bir Hellenistik-Roma Dönemi yerleşmesinin ve nekropolünün tespit edilmiş olmasından bu yerleşmeyle iliş̧kili olabileceği kanaati oluşmaktadır

10 Tepecik Tümülüsü Samsun Kültür Varlıklarını Koruma Bölge Kurulu’nun 04/09/2015 Tarih ve 2890 Sayılı kararı ile I. Derece Arkeolojik Sit Alanı olarak tescil edilmiștir.

${ }^{11}$ Samsun Müze Müdürlüğü, Samsun İli, Kavak İlçesi, Tepecik Mahallesi Tümülüsü Kurtarma Kazısı Çalışması 05/10/2015 tarih ve 217 nolu raporu.
} 
olan kaçak kazı tünelinden mezar odasına inilerek başlanmıştır. Mezar odasının giriş yönünün tespitinin ardından tümülüsün doğu eteğinden 2,80 m.'lik bir genişlikte, etek kısmından merkeze doğru $12 \mathrm{~m}$. uzunluğunda bir dilim açılarak $8 \mathrm{~m}$. derinliğindeki mezar odası girişine ulaşılmıştır. ${ }^{12}$ Giriș yönü olan doğu bölümünün tepe seviyesinden zemin seviyesine kadar, balçık arasına yerleştirilmiş kaba işlenmiş büyük boyutlu taşlarla kaplanmış olduğu gözlendi. Taş dizisinin güneye doğru devam etmemesi tek kullanım için yapılmış olduğu anlaşılan mezar odası girişinin saklanmasının yanı sıra tümülüs dolgu toprağının doğu yöndeki eğime doğru akmasını engellemeyi amaçladığı anlaşılmaktadır. Dromos, ön oda, mezar odası ve sunu odası ile birlikte 10,5 m. uzunluğa sahip olan mezar odası, sert kayaçlardan elde edilmiş, bir yüzü düzeltilmiş blok taşlardan, içerisinde bitkisel fosil bulunduran tortul kayaçlı zemin üzerine inşa edilmiş olup doğu-batı yönünde uzanmaktadır (Görsel 3).

\section{Dromos (A)}

İç mekanlara geçişi sağlayan dromosa baktığımızda; koridor görevi yapan, doğu-batı doğrultusunda uzanan dikdörtgen formlu bir yapıya sahip olduğu görülmektedir. 6,30 m. uzunluğunda, 1,00 m. genişliğinde ve 1,50 m. yüksekliğindeki mekana, 1,10 m. genişliğinde ve 1,78 m. yüksekliğinde bir açıklıktan girilmektedir (Görsel 4). Açıklığı çevreleyen herhangi bir düzenlemeye yer verilmemiş olup balçık toprağına sıkıştırılmış, büyük boyutlu ve diğer mekanlara göre daha kaba yontulmuş taşlardan oluştuğu gözlenmektedir. Dromosun tavan bölümü sıkıștırılmış toprak ve kısmen de balçık aralarına yerleștirilmiş büyük boyutlu sal tașlarından oluşmaktadır. Dromosun ön oda girișine denk gelen kısmında, zemine taş döşenmek suretiyle belirginleştirilmeye çalışıldığı anlaşılmaktadır (Görsel 5). Kapı açıklığının yaklaşık 1,00 m. mesafesinde 1,10 x 0,9 m. ölçülerinde ve 1,40 m. derinliğinde bir kaçak kazı çukuru bulunmaktadır. Çukurun içerisinde bir adet büyük boyutlu taş bloğun bulunmasından, kaçak kazılar sırasında ana giriși kapatan büyük boyutlu taş bloğun bu alana düşürülmeye çalışıldığı anlaşılmaktadır. Duvarlarda ve zeminde tahribat mevcuttur.

\section{Ön Oda (B)}

Doğu-batı yönde uzanan dikdörtgen formlu mekana 0,63 m. x 1,05 m. ölçülerinde bir açıklıkla girilmekte olup kapıyı olușturan lentonun tamamen silme profilli sövelerin ise, kısmen tahrip edildiği görülmektedir (Görsel 6). Kuzey-güney yönlü olarak yapılmış beşik tonozla örtülmüş mekan, 1,55x1,77 m. ölçülerinde ve 1,80 m. yüksekliğindedir (Görsel 7). Kesme taşların büyük bir kısmı yerinden sökülmüș olmakla birlikte, diğer odalara göre daha iyi korunmuş durumdadır. Kenar sekilerinin kısmen mevcudiyetinin korunduğu mekanda taban kaçak kazılarla büyük ölçüde tahrip edilmiş olup, açılan 1,05 m. derinliğindeki çukura iç mekanlardan sökülen blok taşlar yığılmıştır (Görsel 8-9). Söz konusu blok taşları birleștiren kurşun kenetlerin ise söküldüğü görülmektedir.

\section{Mezar Odası (C)}

Doğu-batı doğrultusunda uzanan mekanın girişine ait lento ve söveler tamamen tahrip edilmiş olup izlerden girişin yaklaşık 0,54x1,07 m. ölçülerinde olduğu anlaşılmaktadır (Görsel 10-11). 2,20x2,50 m.'lik ölçüsü ve 2,77 m. yüksekliğiyle yaklaşık kare bir plana sahip olana alana tümülüsün kuzeydoğu yamacından açlıp, güney yönde uzanan ortalama $3 \times 3 \mathrm{~m}$. ölçülere sahip dik eğimli bir tünelle ulaşılmış ve beşik tonoz örtü sistemine ait blok taşlar sökülmek suretiyle içeri girilmiştir. Kaçak kazılarla en fazla tahrip edilen mekanın beden duvarları büyük oranda korunurken, kuzey-güney yönlü olarak yapılmış olan beşik tonozlu örtüsü tamamen sökülmüş ve tümülüsün dolgu toprağıyla iç mekan kısmen dolmuştur. Mekanın batı duvarı önünde 1,10x2,50 m. ölçülerinde ve 1,05 m. derinliğinde bir kaçak kazı çukuru bulunmaktadır. Klineye ait ele geçen kalıntılardan orijinalinde iki adet büyük boyutlu taştan oluşturulduğu anlaşılmaktadır. ${ }^{13}$ Mezar odasında gerçekleștirilen bu çalışmalar sırasında; blok kesme taşları birbirine bağlayan demir kenet ve bağlantı çubukları ile

12 Tümülüsün bütünlüğünü korumak adına ayrıca bir açma açılmadığından krepis duvarı olup olmadığı hakkında bilgi edinilememiştir. Ayrıca güney ve batı yüzeyindeki kaçak kazı çukurları kendi toprağı ile doldurularak doğal görüntüsüne kavuşturulmuştur.

13 Mekandaki toprak malzeme dışarı taşınarak restorasyonda kullanılmak üzere muhafaza altına alınırken, blok taşlar bulundukları yerde korunmuştur. 
aralara dökülen kurşun parçaları (Görsel 14), bitki fosilli tortul kayaç parçaları (Görsel 15), insan ve çeşitli hayvanlara ait kemik kalıntılarının yanı sıra kahverengi, devetüyü, siyah hamurlu seramiklerle, ince cidarlı kaliteli "Kızılırmak Havzası Kapları" (Zoroğlu, 1986, 459; 1987, 65; Dönmez, 2001, 94) veya "Kızılırmak Havzası Boyalı Kapları" (Zoroğlu, 1979, 345-354) gibi adlarla tanımlanan bitkisel ve bant boya bezekli çanak-çömlek parçaları (Görsel 16-21) ele geçmiștir. Bu tanımlama ile Orta Anadolu'nun Kızılırmak kavsi içinde kalan kısmı ile kuzeyde KızılırmakYeşilırmak arasında kalan bölgede MÖ 3. yüzyılın başlarından Augustus döneminin sonuna kadar üretilen seramikler kastedilmektedir (Zoroğlu, 1986, 459). Söz konusu boya bezekli bu çanak çömlek parçaları, Orta Karadeniz Bölgesi'nde yapılan araştırmalarda sıkça görülmekte olup, Kırşehir, Çorum, Yozgat, Tokat, Sivas, Amasya ve Samsun illerini kapsayan geniş̧ bir coğrafi alanda karşımıza çıkmaktadır (Dönmez, 2001, 94). Geç Demir Çağının geç evre sürecinin devamında, Kızılırmak kavisi içinde karşımıza çıkan bu seramikler, Demir Çağı gelenekleri ve yerel özelliklerini sürdürdükleri için "Kızılırmak Havzası Hellenistik Dönem Yerel Boya Bezekli Çanak-Çömleği" olarak da tanımlanmaktadır (Dönmez, 2001, 94). Bu seramiklerin en belirgin özelliği; Tepecik Tümülüs'ünde bulunan seramiklerde görüldüğü gibi, üzerlerinde bant bezemesi (Dönmez, 2003, 4) ile sarmaşık yaprağı motiflerinin sıkça kullanılmış olmasıdır. Bu yaprak bezemesi Hellenistik Dönem boyalı seramikleri için oldukça önemli bir tarihleme unsuru olușturmaktadır. Bu kapların formlarına baktığımızda ise, çoğunlukla kenarı dışa uzantılı ve karnı dirsek yapan bir form yapısına sahip oldukları görülür. Tepecik Tümülüsü'nde bulunan seramikler de form ve bezeme özelliklerinden yola çıkıldığında MÖ 2. yüzyıla tarihlenmişlerdir.

\section{Sunu Odası (D)}

Odanın giriş açılılı̆ı ve bu yöndeki duvarı büyük oranda sökülmüş durumdadır (Görsel 12-13). Doğu-batı yönde uzanan diğer odalardan farklı olarak, kuzey- güney doğrultuda uzanan mekan 0,93x240 m. ölçüleri ve 1,53 m. yüksekliğiyle dikdörtgen bir plana sahiptir. ${ }^{14}$ Diğer odalarda olduğu gibi yine kuzey-güney yönlü beşik tonozlu bir örtüye sahip olan mekanın, tonoz örtüsünün sadece güney bölümü korunmuş durumdadır. Odanın duvarlarının tamamına yakını sökülerek, toprak dolgu ile birleşmiş ve kuzey-güney yönde beden duvarı arkasına tüneller açılmıştır. ${ }^{15}$

\section{Tartışma ve Sonuç}

Samsun ve ilçelerinde çok sayıda Tümülüs tespit ve tescil edilmesine karşın, bunlardan çok azının kazısı yapılabilmiştir. Hellenistik ve Roma dönemlerine tarihlenen bu tümülüsler incelendiğinde genel olarak; bir mezar odası ve ön oda olmak üzere iki bölümden oluştukları ve bu odalara bir dromosla girildiği görülmektedir. Mezar odalarının üzeri kesme taştan yapılmış, beşik tonoz örtüyle kaplıdır. Hellenistik dönemden yoğun olarak karşımıza çıkan bu örtü sistemi, Roma ve Bizans Dönemlerinde de sıkça karşımıza çıkmaktadır. Bölgedeki kazısı yapılan tümülüslere baktığımızda; tamamen kesme taştan inşa edilen dromos ve mezar odasının, üzerinin taş ve topraktan oluşan suni bir tepecik şeklinde örtülmüş olduğu ya da yığma toprak altında yer alan mezar odasının, konglomera tortul kayaca oyularak yapıldığı görülmektedir (Akok, 1948, 835-853; Özsait, 2003, 273-284; Atasoy-Endoğru-Dönmez, 2005, 153-165; Ünan, 2009, 3-4; 2013, 394). Samsun'da Tepecik Tümülüsü'nde olduğu gibi kesme taşlarla dromosu, ön odası ve mezar odası inşa edilen Tümülüsler; Atakent, İkiztepe ve Lerdüge Tümülüsleri'dir. Tümülüslerin yığma topraklarının ortalama taban çapları 20-30 m. arasında değişmektedir. Baruthane, Dondortepe, Lerdüge Tümülüsleri'nde olduğu gibi, bazılarının mezar odaları sıvalıdır (Atasoy-Endoğru-Dönmez, 2005, 154; Ünan, 2009, 4). Baruthane ve İkiztepe Tümülüsleri Hellenistik Dönem'e; Lerdüğe, Toptepe ve Dondortepe Tümülüsü ise Hellenistik ve Roma Dönemlerine tarihlendirilmiştir. Samsun'daki tümülüsler genel olarak hâkim konumdaki tepeler üzerine inşa edilmişlerken Tepecik Tümülüsü'nün düz bir arazi üzerine konumlandığı görülmektedir. Dromos girişleri genelde doğu yönlüdür ancak, Dondortepe Tümülüsü'nde kuzeybatı yöne bakan ve sonradan eklendiği anlaşılan ikinci bir dromosa yer verilmiştir (Ünan, 2013, 394).

Tümülüste bulunan seramik malzemelerimizi genel olarak değerlendirecek olursak (Görsel 20-21); dik, dışa kalınlaştırılmış ve düzleştirilmiş ağız kenarlı derin kaseler, dışa çekik ağızlı, kısa boyunlu çömlekler (Görsel 18), monokrom ve polikrom boya bezemeli amorflardan oluşmaktadır. İnce

14 Odanın doğu-batı yönlü olmayıșı ve içinde sekinin bulunmayışından sunu odası olduğu kanaatine ulaşılmıştır.

${ }^{15} \mathrm{Bu}$ mekanda bulunan blok ve moloz taşlar uygun alanlara dizilerek restorasyon çalışmalarında kullanılmak üzere muhafaza altına alınmıştır. 
çeperli, yüksek bir teknik ve artistik işçiliği olan "Nitelikli Mal/Fine Ware" olarak adlandırabileceğimiz karakteristik özellikli parçalar üzerindeki pembe, krem, açık krem, kirli beyaz ve açık, pembemsi kahve hamurlu, hamurunun renginde astarlı ve iyi açkllıdırlar. Bu kapların bir kısmı bezemeli bir kısmı ise bezemesizdir. Yuvarlak omurgalı çanağın düzleștirilmiş ağız kenarı üzerine ve ağız içine koyu kahverengi renkte boya ile uygulanmış kalın band dizileri ve gövde üzerine siyah paralel bant bezeme yapılmıştır. Krem astar üzerine kırmızı, koyu kahverengi boya bezeme siyah ve kırmızı renkte paralel bantlar, yine krem astar üzerine siyah dallı kırmızı renkte yaprak motifleri işlenmiştir (Görsel 16-17). Yoğun tahribata maruz kaldığı, mezar odası mimarisinde kayıpların olduğu Tepecik Tümülüsü'nde gerçekleştirilen çalışmalarda ele geçen çanak-çömlek parçaları ile mimari birlikte bir bütün olarak değerlendirildiğinde, mezar yapısının MÖ 2. yüzyılda inşa edildiği düşünülmektedir. Tümülüs içinde farklı dönemlere ait herhangi bir buluntuya rastlanmamış olması, ikinci bir kullanım geçirmediğini göstermektedir. Bu kapsamda Tepecik Tümülüsü gerek mimari formu ve gerekse buluntularıyla bölgenin ölü gömme adetleri ve teknolojisi konusunda literatüre oldukça önemli bilgiler sunmaktadır. Tümülüslerin diğer arkeolojik kalıntılar gibi dünya kültürel mirasının önemli birer parçası olduğu aşikârdır. Onları sadece basit yığma tepeler olarak değerlendirmek doğru bir yaklaşım değildir. İnsanların bilinçlendirilerek tümülüslere zarar vermesi önlenmeli ve döneminin sosyo-ekonomik yapısını, mimarisini ve buluntularıyla sanatsal anlayışını yansıtan, tarihi vesika niteliğindeki tümülüslerin gelecek nesillere sağlam olarak ulaştırılmaları sağlanmalıdır.

\section{Yazar Katkıları}

Çalışmaya 1. yazar \%50, 2. yazar \%50 katkı sağlamıştır.

\section{Kaynakça}

Akok, M. (1948). Samsun ili havza ilçesinin lerdüge köyünde bulunan tümülüsler. Belleten XII(48), 835-853.

Alkım, U. B., Alkım, H. ve Bilgi, Ö. (1988). Íkiztepe I. Ankara: TTKY.

Avşar, G. (2016). Anadolu Tümülüslerinin Tipolojik Açıdan İncelenmesi. (Yayımlanmamış Yüksek Lisans Tezi), Hitit Üniversitesi Sosyal Bilimler Enstitüsü, Çorum.

Atasoy, (1997). Amisos Karadeniz Kiyısında Bir Kent. Samsun: Samoto Oto Yayını.

Atasoy, , Endoğru, M., Dönmez, Ș. (2005). Samsun-Baruthane tümülüsleri kurtarma kazısı. Anadolu Araştırmaları Dergisi, XVIII(2), 153-165.

Bilgi, Ö. (1999). İkiztepe in the late iron age. Anatolian Studies, 49, 4. Proceedings of the Fourth Anatolian Iron Ages Colloquium Held at Mersin, 19-23 May 1997, 27-54.

Bilgi, Ö., Atasoy, Ș. Dönmez, L. Summerer (2005). Samsun (Amisos) bölgesinin kültürel gelişimi projesi. Belleten, 68(252), 387-402.

Boardman, J. (1994). The Diffusion of Classical Art in Antiquity. London: Princeton University Pre

Dinç, R. (1993). Lydia Tümülüsleri. (Yayımlanmamıș Doktora Tezi), Ege Üniversitesi Sosyal Bilimler Enstitüsü, İzmir.

Dönmez, Ş. (2001). Amasya müzesinden boya bezekli iki çanak ıșığında kızılırmak kavsi geç demir ve helenistik çağları çanak-çömleğine yeni bir bakış. TÜBA-AR, 4, 89-99.

Dönmez, Ş. (2003). Yeni bulguların ışığında orta karadeniz bölgesi demir çağı çanak-çömleğine bir bakış. Anadolu/Anatolia, 24, 1-17.

Erdoğan, (2007). Gordion Tümülüsleri Ișığında Frigler'de Oda Mezarlara Ölü Gömme Gelenekleri. (Yayımlanmamış Yüksek Lisans Tezi), Sosyal Bilimler Enstitüsü, Konya.

Hoddinott R. F. (1975). Bulgaria in Antiquity. An Archaeological Introduction. London: Ernest Benn Limited.

Hoddinott R. F. (1981). The Thracian (Ancient Peoples \& Places, 98). London: Thames and Hudson. 
Mansel, A. M. (1974). Gemlik tümülüs mezarı. Belleten, 38(150), 181-189.

Mansel, A. M. (1995). Ege ve Yunan Tarihi. Ankara: TTKY.

Mert, İ. H., Şahin, R., Altın, A. A. (2018). Prusa ad olympum'dan (Bursa) bir oda mezar. International Journal of Social Inquiry, 11(1), 203-254

Metin M. (2014). 2012 Yılı Akyurt- Kalaba tümülüsleri kurtarma kazısı. Anadolu/Anatolia, 40, 145178.

Onurkan, (1988). Doğu Trakya Tümülüsleri Maden Eserleri. Ankara: TTKY.

Ökse, A.T. (2005). Eski çağdan günümüze ölü gömme ve anma gelenekleri. Türk Arkeoloji ve Etnografya Dergisi, 5, 1-8.

Özgüç. T. (1948). Samsun hafriyatının 1941-1942 neticeleri. III. Türk Tarih Kongresi, 393-419.

Özsait, M. (2003). 2002 yılı samsun-amasya yüzey araştırmalarının ilk sonuçları. Araştırma Sonuçları Toplantısı, 21(2), 273-284.

Öztekin, İ. E. (2006). MÖ 1. Binde Anadolu'da Tümülüs Geleneğinin Kronolojik Gelişimi ve Coğrafi Yayılımı. (Yayımlanmamış Yüksek lisans Tezi), Hacettepe Üniversitesi Sosyal Bilimler Enstitüsü, Ankara.

Sevinç, N., Treister, M. (2003). Metalwork from the dardanos tumulu Studia Troica, 13, 215-260.

Şahin, M. (2009). Görükle mezarı kurtarma kazısı 2006 yılı sonuç raporu. Kazı Sonuçları Toplantısı, $30(4), 25-38$.

Tekçam, T. (2007). Arkeoloji Sözlüğü. İstanbul: Alfa Yayınları.

Temür, A., Yiğitpaşa, D. (2020a). Neoklaudiopolis antik kenti ve territoryumu 2018 yüzey araştırması ve envanter çalışmaları. History Studies, 12(2), 619-654.

Temür, A., Yiğitpaşa, D. (2020b). Neoklaudiopolis antik kenti ve territoryumu 2019 yüzey araştırması ve envanter çalışmaları. History Studies, 12(6), 2865-2894.

Tsetskhladze, G. R. (2005). Karadeniz'in Tarih ve Arkeoloji Üzerine. (Yay. Haz. Atasoy), İstanbul: Ege Yayınları.

Tsetskhladze, G. R. (2020). Who built the scythian and thracian royal and elite tombs? Oxford Journal of Archaeology, 17(1), 55-92.

Ünan, (2009). Samsun/Dondortepe (hacı ismail) tümülüsü. Masrop E-Dergi, 4, 1-28.

Ünan, (2013). Tunç çağı'ndan roma dönemi'ne, amisos ve çevresinde yer alan mezar tipleri ve ölü gömme adetleri üzerine genel bir değerlendirme. Güneş Karadeniz'den Doğar Sümer Atasoy'a Armağan Yazılar, (Ed. Ş. Dönmez), 387-414.

Venedikov, I., Gerassimov, T. (1975). Thracian Art Treasure Sofia: Bulgarski Houdozhnik Publishing House.

Yıldırım, Ş. (2008). Doğu Trakya'da Mezar Tepelerinin Ortaya Çı kışı ve Gelişimi. (Yayımlanmamış Doktora Tezi), Ankara Üniversitesi Sosyal Bilimler Enstitüsü, Ankara.

Yıldırım, Ş. (2010). Askertepe tümülüsü. Anadolu/Anatolia, 36, 149-178.

Yıldırım, Ş. (2018). Gökbel köyü hamas kıranı tümülüsü. Hitit Üniversitesi Sosyal Bilimler Enstitüsü Dergisi, ANARSAN Sempozyumu Özel Sayısı, 11(2), 1295-1319.

Young, R. (1981). Three Great Early Tumuli. Philadelphia: University of Pennsylvania.

Yücel Ç. (2017). Malatya tümülüsleri hakkında bir değerlendirme. Ínönü Üniversitesi, Uluslararası Sosyal Bilimler Dergisi, 6(1), 161-174.

Zoroğlu, L (1979). Eskiyapar'da bulunan kızılırmak havzası (galat denilen) boyalı seramikleri. VIII. Türk Tarih Kongresi, I. Cilt, Ankara, 239-252 
Zoroğlu, L (1986). Kızılırmak havzası kaplarının biçim ve süs gelişimine örnekler. IX. Türk Tarih Kongresi, I. Cilt, Ankara, 459-472.

Zoroğlu, L. (1987). Kızılırmak havzası kapları. Anadolu Demir Çağları Sempozyumu, 24-27 Nisan 1984 (Ed. A. Çilingiroğlu), İzmir, 65-69.

\section{Extended Abstract}

Tepecik Tumulus, which is the subject of the study, is about $2 \mathrm{~km}$ far from Samsun Province's Kavak District, is located in the north of the asphalt of Kavak-Tepecik District. The tumulus is about 8-10 m. in height and 20-30 m. in diameter and it is understood from the topography of the surrounding land that it is located on a flat land. Over time, it was out of sight due to its surroundings and the plant tissue formed on it, and it was exposed to many illicit digging In the first examinations of the tumulus; illegal excavations created deep pits in the outer earth fill of the tumulus, and the vaulted ceiling covering of the burial chamber was destroyed and collapsed. It is seen that the burial chamber of the tumulus was not at the center of the hill, but was shifted from the center to the north-east direction in order to prevent any robbery attempt The Tumulus, which was built of cut block stones joined with lead clamps and iron connecting rods, consists of a dromos, anterior chamber, a tomb chamber and a presentation room. First to the studies; to evaluate the situation, the burial chamber was reached from the illegal excavation tunnel, which runs south from the northeast skirt of the tumulus and is approximately $6 \mathrm{~m}$ deep from the top of the hill. After the spotting the entrance direction of the grave chamber, the entrance to the burial chamber with a depth of $8 \mathrm{~m}$ was reached by opening a $2.80 \mathrm{~m}$ wide slice from the eastern skirt of the tumulus, $12 \mathrm{~m}$ long from the skirt to the center. It is understood that the row of stones does not reach to the south and aims to hide the entrance of the tomb chamber, which is understood to be for a single use, as well as preventing the tumulus filling soil from flowing towards the slope in the east. The tomb chamber, dromos, anterior chamber, burial chamber and presentation room are in total $10.5 \mathrm{~m}$ long. It was built on a rocky ground containing vegetable fossils, and extends in the east-west direction.

When we look at the dromos (A) that provides the transition to interior spaces; It is seen that it has a rectangular structure that functions as a corridor and extends in the east-west direction. The venue is $6,30 \mathrm{~m}$. long, $1.00 \mathrm{~m}$. wide and $1.50 \mathrm{~m}$. in height. This place is entered from somewhere $1,10 \mathrm{~m}$. wide and $1.78 \mathrm{~m}$. in height. The ceiling of the dromos consists of compacted soil and partially large raft stones placed between mud. It is understood that the part of the dromos, which intersects with the entrance to the anterior room, was tried to be made clear by laying stones on the floor.

Front Room (B) is $0.63 \mathrm{~m}$. by $1.05 \mathrm{~m}$. It is observed that the lintel forming the door has been completely destroyed and the jambs with a wiping profile have been partially destroyed. Covered with a barrel vault built in a northsouth direction, the room is 1.55 by $1.77 \mathrm{~m}$. and 1,80 m. in height. It is seen that the lead clamps connecting the block stones in question have been removed.

The Grave Room (C), the lintel and jambs belonging to the entrance of the room extending in the east-west direction have been completely destroyed. The area measures approximately square plan with its $2.20 \times 2.50 \mathrm{~m}$. and $2.77 \mathrm{~m}$. in height. This area is accessed by a steeply inclined tunnel with an average dimension of $3 \times 3 \mathrm{~m}$, opening from the northeast slope of the tumulus and extending in the south direction. This area is accessed by a steeply inclined tunnel with an average dimension of $3 \times 3 \mathrm{~m}$ extending in the south direction, opening from the northeast slope of the tumulu The barrel-vaulted cover, which was built in a north-south direction, has been completely removed.

During these studies carried out in the burial chamber; we were found iron clamps and connecting rods connecting the block cut stones and lead fragments cast in between, fragments of plant fossil sedimentary rock, bone remains from human and various animals, as well as brown, buff paste ceramics, thin-walled, herbal and band-paint decorated Hellenistic period (II. Century B.C.) pottery piece

The entrance opening of the Presentation Room (D) and the wall in this direction have been mostly removed. Unlike the other rooms extending in the east-west direction, the room extending in the north-south direction has a rectangular plan of $0.93 \times 240 \times 1.53 \mathrm{~m}$. As in the other rooms, it has a north-south direction barrel-vaulted cover. When we look at the tumuli excavated in the region; It is seen that the dromos and the tomb chamber, which was built entirely from cut stones, were covered in the form of an artificial hill made of stone and soil, or the burial chamber, which is under the piled soil, was carved into conglomerate sedimentary rock. Tumuli's dromos, anterior chamber and burial chamber were built with cutting stones, as in the Tepecik Tumulus in Samsun; Atakent, Ikiztepe and Lerdüge Tumuli. While the tumuli in Samsun are generally built on dominant hills, it is seen that the Tepecik Tumulus is located on a flat land. 


\section{Katalog*}

\section{Levha 1 (1-12)}

1- Oldukça kaba işlenmiş taş kap, ağız çapı $8 \mathrm{~cm}$.

2- Derin çanak, ağız çapı 10 cm., kahverengi (5 YR 6/6) hamurlu, beyazımsı krem (7.5 YR 8/2) renginde astarl, ince kum ve az kireç katkılı, iyi pişirilmiş, açkıll, çark yapımı.

3- Çömlek, ağız çapı 10,5 cm., kahverengi (5 YR 5/6) hamurlu, krem (7.5 YR 8/4) renginde astarll, ince kum ve az kireç katkıll, iyi pişirilmiş, açkıll, çark yapımı, bezeme siyah (5 YR 2.5/1) ve koyu kahverengi (2.5 YR 5/6).

4- Çömlek, ağız çapı 14 cm., kahverengi (5 YR 5/6) hamurlu, astarı dökülmüş, orta kum ve kireç katkılı, iyi pişirilmiş, açkılı, çark yapımı.

5- Çömlek, ağız çapı $14 \mathrm{~cm}$., kahverengi (5 YR 6/6) hamurlu, hamurunun renginde astarll, orta kum ve kireç katkılı, kötü pişirilmiş, açkılı, çark yapımı.

6- Gövde parçası, kahverengi (5 YR 5/6) hamurlu, beyazımsı krem (7.5 YR 8/2) renginde astarlı, ince kum katkılı, iyi pişirilmiş, açkılı, çark yapımı, siyah (5 YR 2.5/1) ve koyu kahverengi (2.5 YR 5/6).

7- Gövde parçası, kahverengi (5 YR 5/6) hamurlu, pembemsi krem 0 renginde astarl,, ince kum katkıll, iyi pişirilmiş, açkılı, çark yapımı, bezeme siyah (5 YR 2.5/1) ve kahvemsi kırmızı (2.5 YR 4/4). 8- Gövde parçası, kahverengi (5 YR 5/6) hamurlu, krem 0 renginde astarlı, ince kum katkıll, iyi pişirilmiş, açkılı, çark yapımı, bezeme bezeme siyah (5 YR 3/1) ve kırmızımsı kahverengi (2.5 YR $5 / 8$ ).

9- Gövde parçası, kahverengi (5 YR 5/6) hamurlu, hamurunun renginde astarl,, ince kum katkıll, iyi pişirilmiş, açkllı, çark yapımı, bezeme koyu kahverengi (2.5 YR 5/6).

10- Gövde parçası, kahverengi (5 YR 5/6) hamurlu, beyazımsı krem (7.5 YR 8/2) renginde astarlı, ince kum katkıll, iyi pişirilmiş, açkıll, çark yapımı, bezeme siyah (5 YR 3/1), kahvemsi kırmızı (2.5 YR 4/4), kahverengi (7.5 YR 7/6).

11- Gövde parçası, kahverengi (5 YR 5/6) hamurlu, hamurunun renginde astarlı, ince kum katkılı, iyi pişirilmiş, açkılı, çark yapımı, bezeme siyah (5 YR 3/1).

12- Gövde parçası, kahverengi (5 YR 5/6) hamurlu, hamurunun renginde astarlı, ince kum katkıll, iyi pişirilmiş, açkılı, çark yapımı, bezeme siyah (5 YR 3/1).

\section{Levha 2 (1-11)}

1- Gövde parçası, kahverengi (5 YR 5/6) hamurlu, hamurunun renginde astarl, ince kum katkıll, iyi pişirilmiş, açkılı, çark yapımı.

2- Gövde parçası, kahverengi (5 YR 5/6) hamurlu, beyazımsı krem (7.5 YR 8/2) renginde astarlı, ince kum katkıll, iyi pişirilmiş, açkıll, çark yapımı.

3- Gövde parçası, kahverengi (5 YR 5/6) hamurlu, beyazımsı krem (7.5 YR 8/2) renginde astarl, ince kum katkıll, iyi pişirilmiş, açkılı, çark yapımı.

4- Gövde parçası, kahverengi (5 YR 6/6) hamurlu, hamurunun renginde astarlı, ince kum katkıll, orta pişirilmiş, açkılı, çark yapımı.

5- Gövde parçası, kahverengi (5 YR 5/6) hamurlu, hamurunun renginde astarl,, ince kum katkıll, iyi pişirilmiş, açkılı, çark yapımı, bezeme kırmızı.

6- Gövde parçası, kahverengi (7.5 YR 8/6) hamurlu, kahvemsi kırmızı (2.5 YR 5/6) renginde astarlı, ince kum katkılı, iyi pişirilmiş, açkılı, çark yapımı, bezeme siyah (5 YR 3/1).

7- Kulp, kahverengi (5 YR 5/6) hamurlu, hamurunun renginde astarll, orta kum katkıll, iyi pişirilmiş, açkılı, çark yapımı.

8- Kulp, kahverengi (5 YR 5/6) hamurlu, hamurunun renginde astarll, orta kum katkılı, iyi pişirilmiş, açkılı, çark yapımı.

9-11- Taș alet.

\footnotetext{
* Kum içindeki tanelerin 1 mm. çapından daha küçük olduğu durumlarda ‘İnce kum katkı'; 2 mm. ise 'orta kum katkı'; 2 mm'den daha büyük ise 'kaba kum katkı' kullanılmıştır. Özü tamamen siyah ya da kurşuni renkteyse 'kötü pişirilmiş'; iç ve dış çeper hamurunun renginde, öz siyah renkteyse 'orta pişirilmiş'; öz tümüyle hamurunun rengindeyse ve kesitte bir renk değişimi yoksa 'iyi pişirilmiş', terimleri kullanılmıştır. Renkler için Munsell Soil Color Charts (GretagMacbeth 2000) katalogundan yararlanılmıştır.
} 
Yiğitpaşa, D., ve Temür, A., (2021). “Kavak Tepecik Tümülüsü Üzerine Gözlemler” ODUSOBİAD, 11(2), $460 \cdot 451-466$, doi: 10.48146/odusobiad.916029
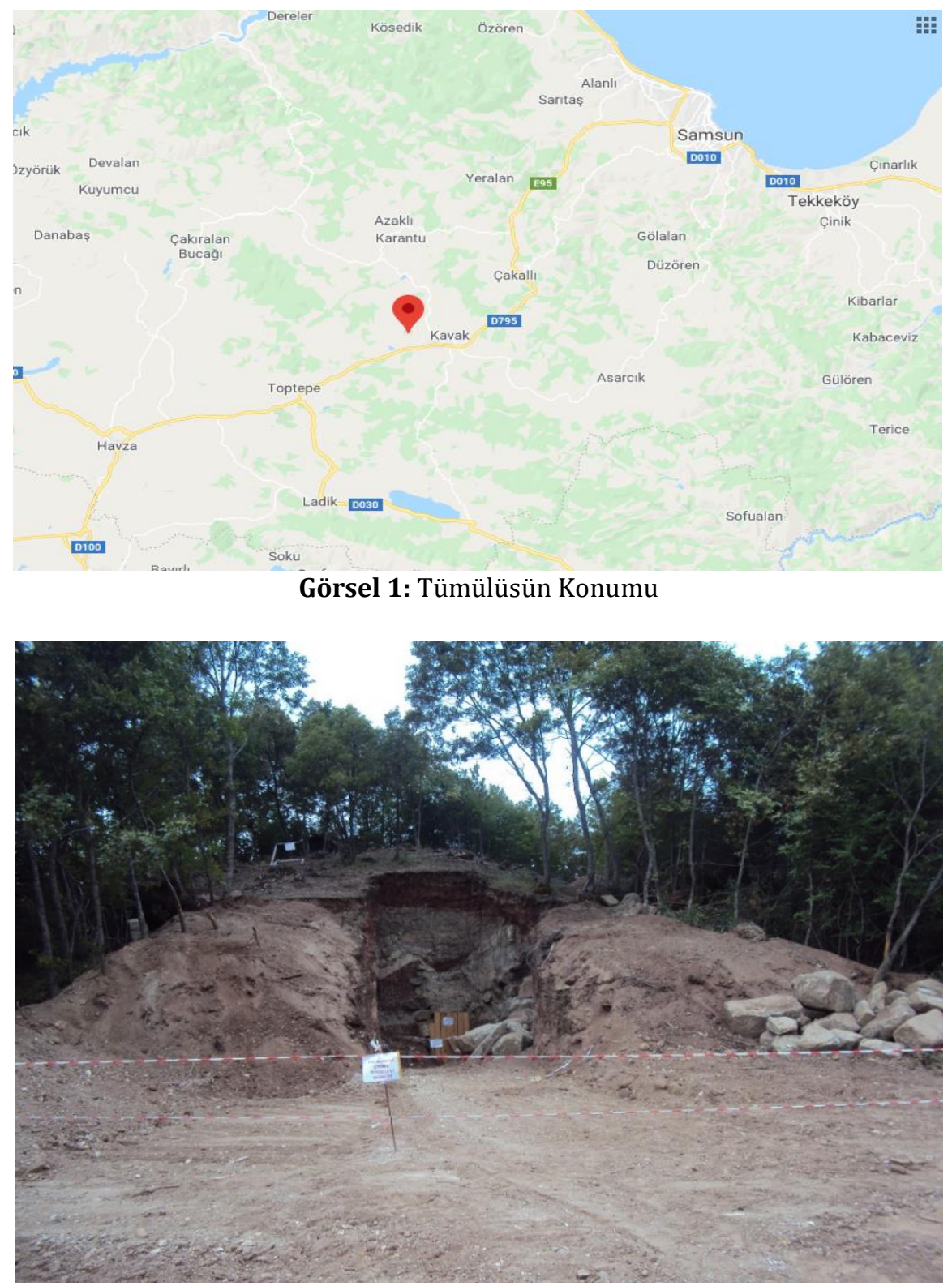

Görsel 2: Genel Görünümü

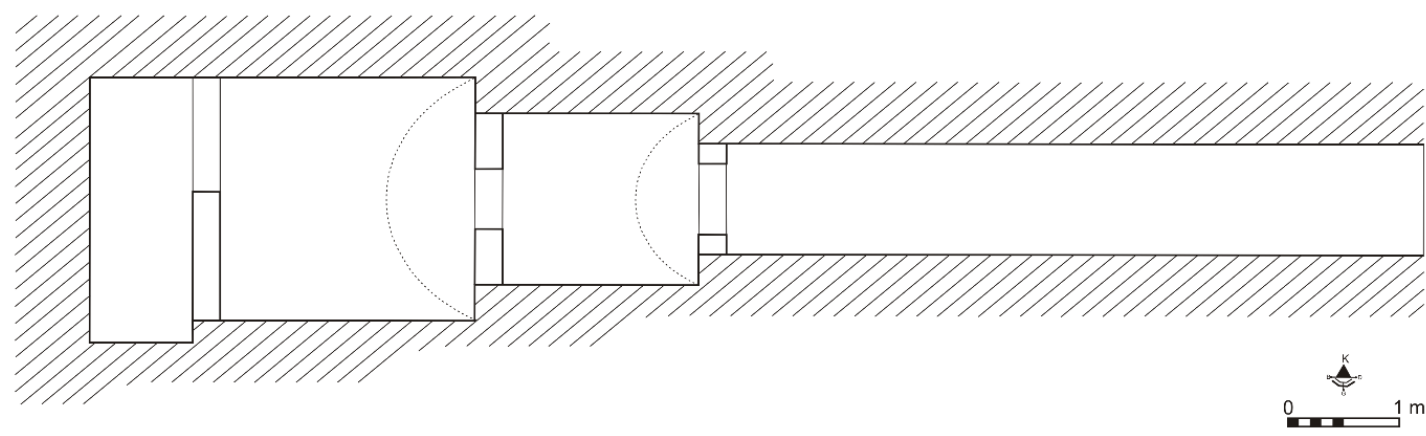

Görsel 3: Tümülüsün Planı (Sam. Müz. Arş.) 


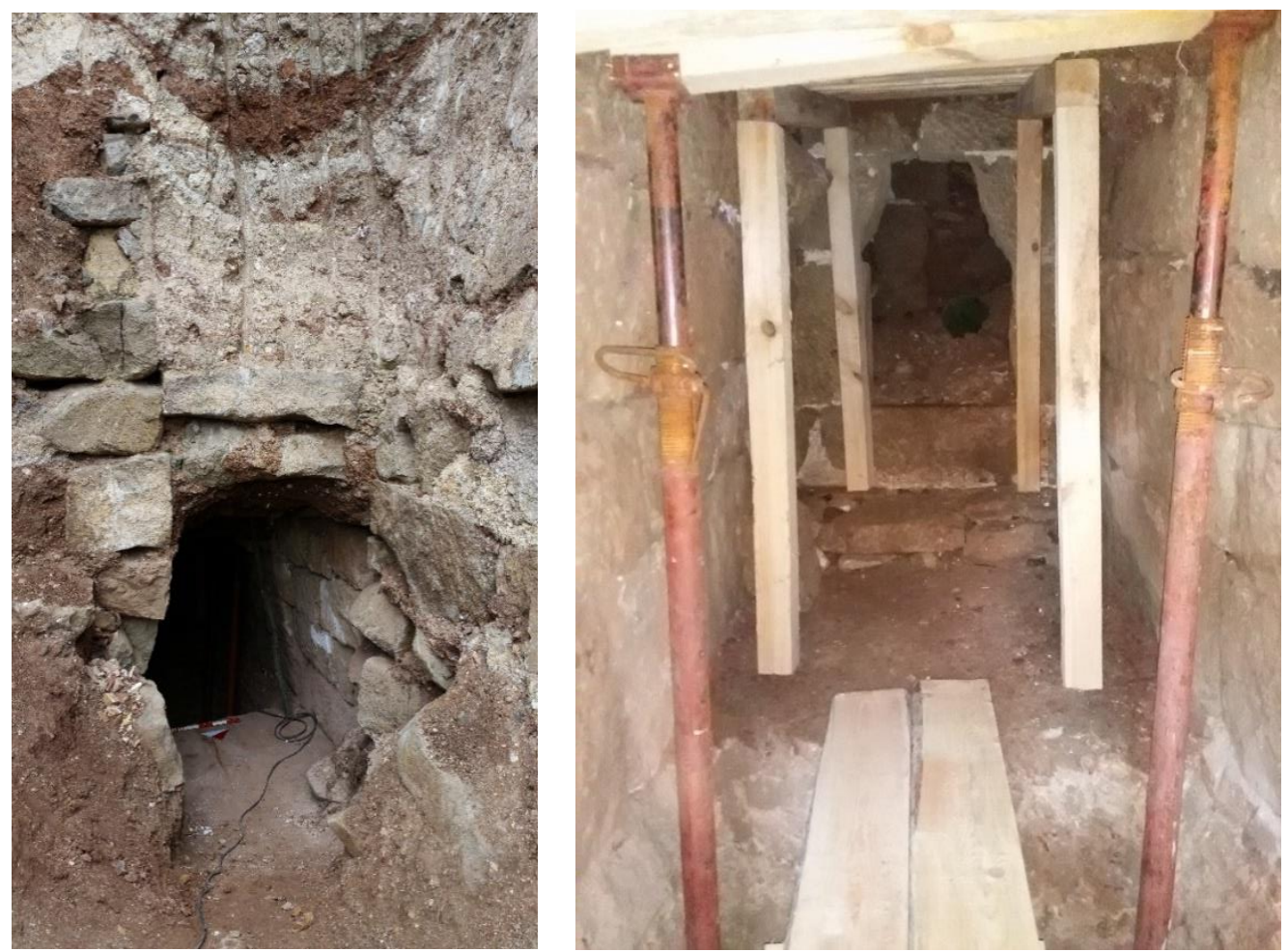

Görsel 4-5: Giriș ve Dromos Kısmı
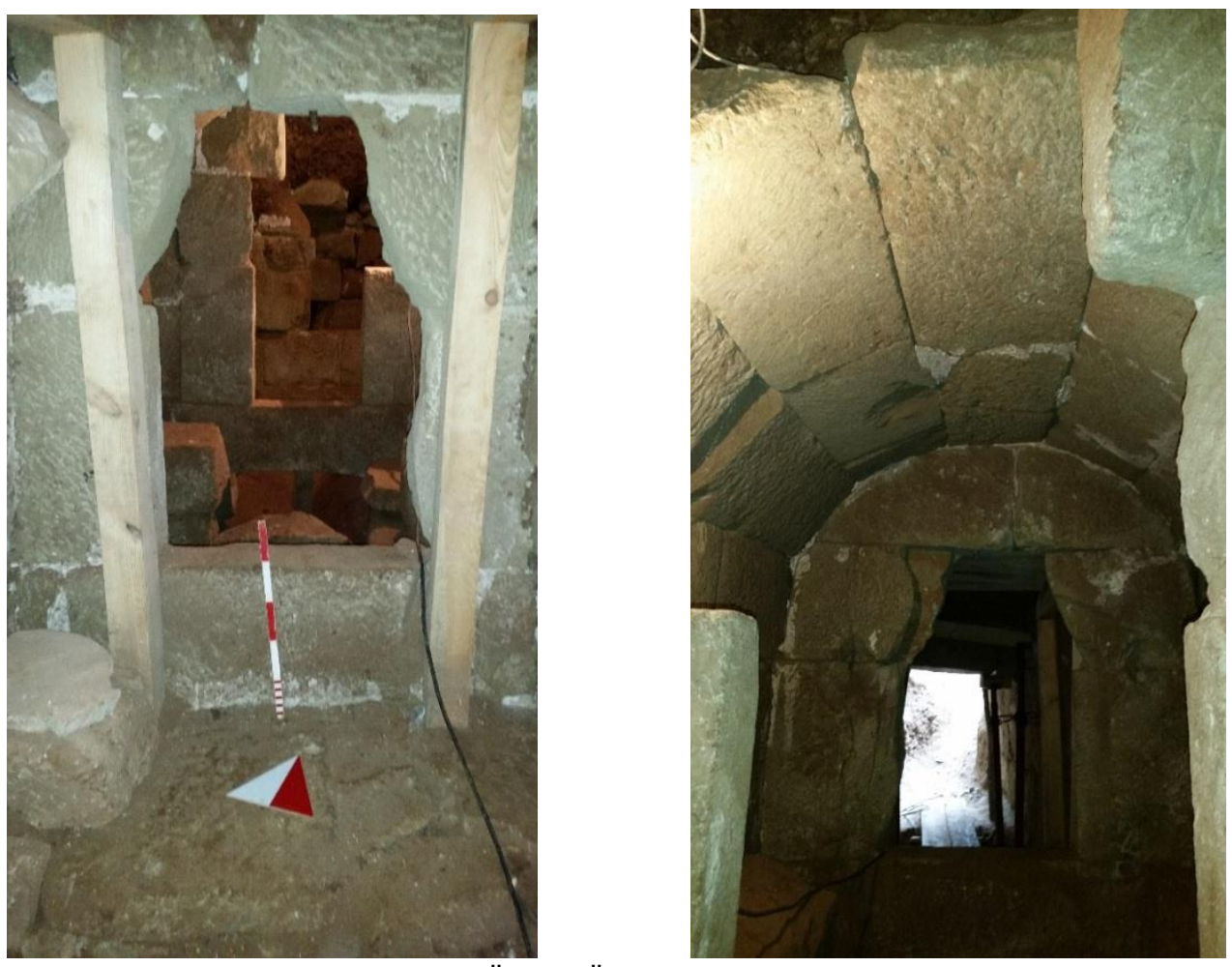

Görsel 6-7: Tonoz Örtülü Ön Oda ve Diğer Odalara Geçiş 
Yiğitpaşa, D., ve Temür, A., (2021). “Kavak Tepecik Tümülüsü Üzerine Gözlemler” ODUSOBİAD, 11(2),

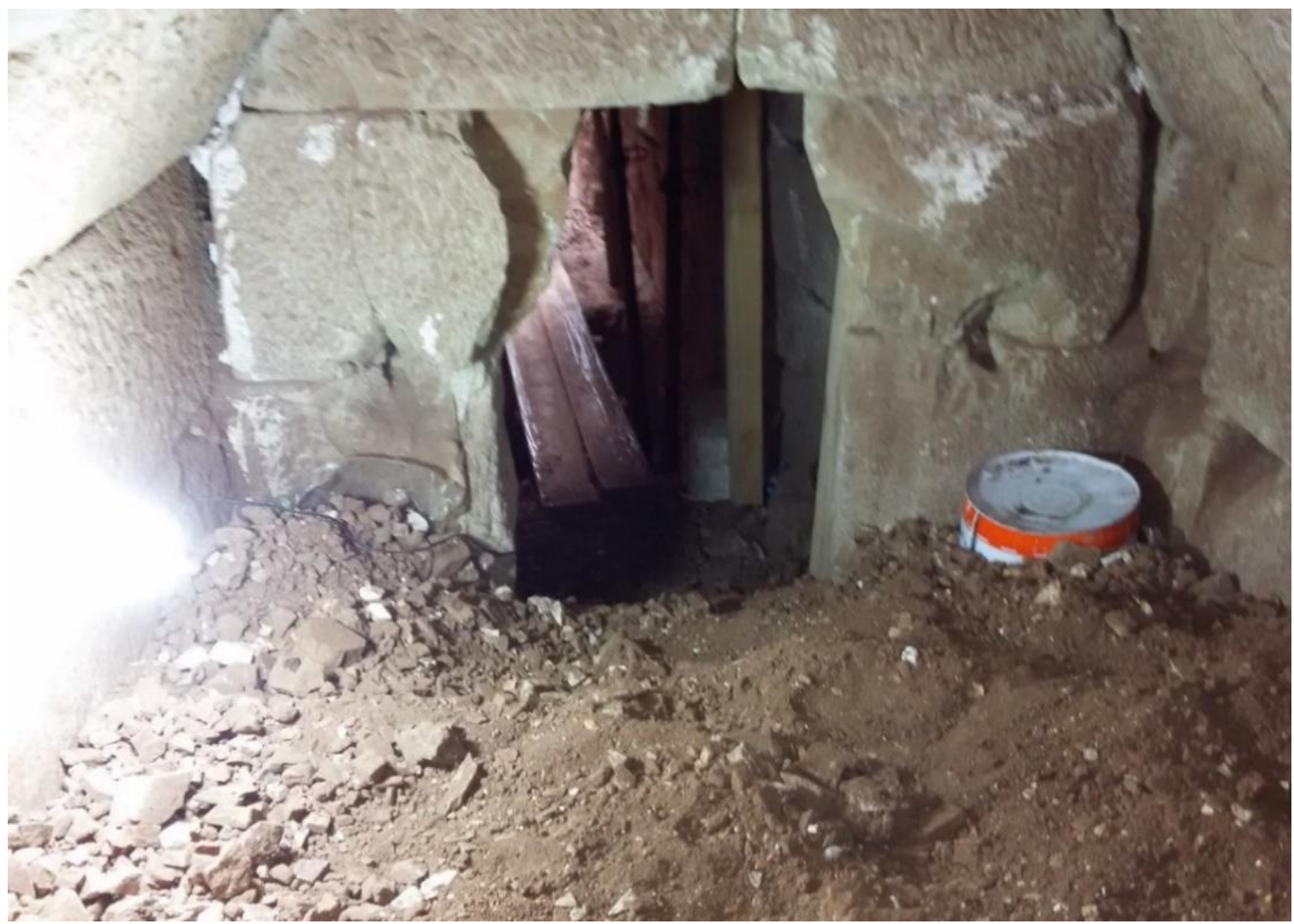

Görsel 8: Ön Odanın Girişi

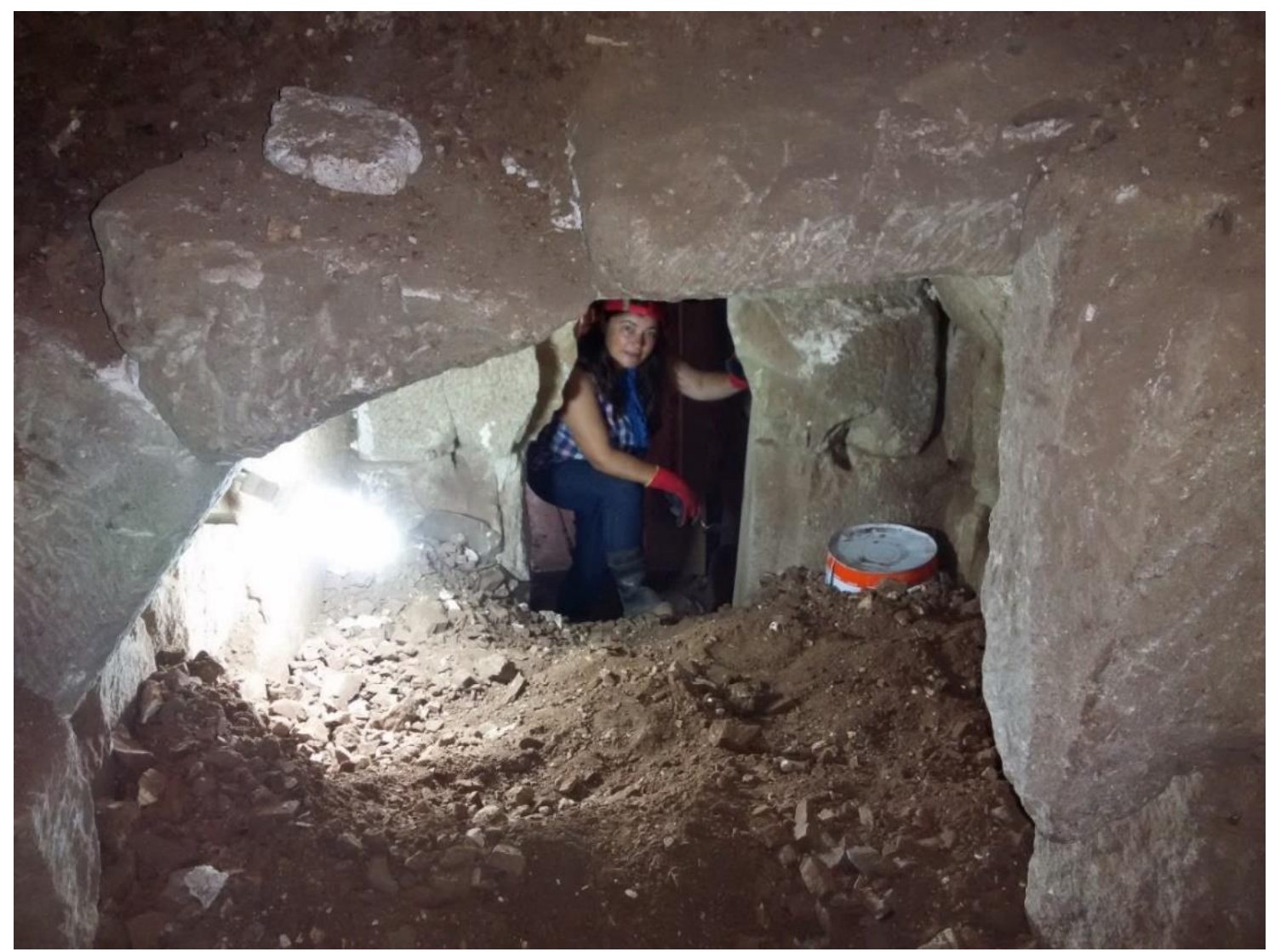

Görsel 9: Ön Oda 

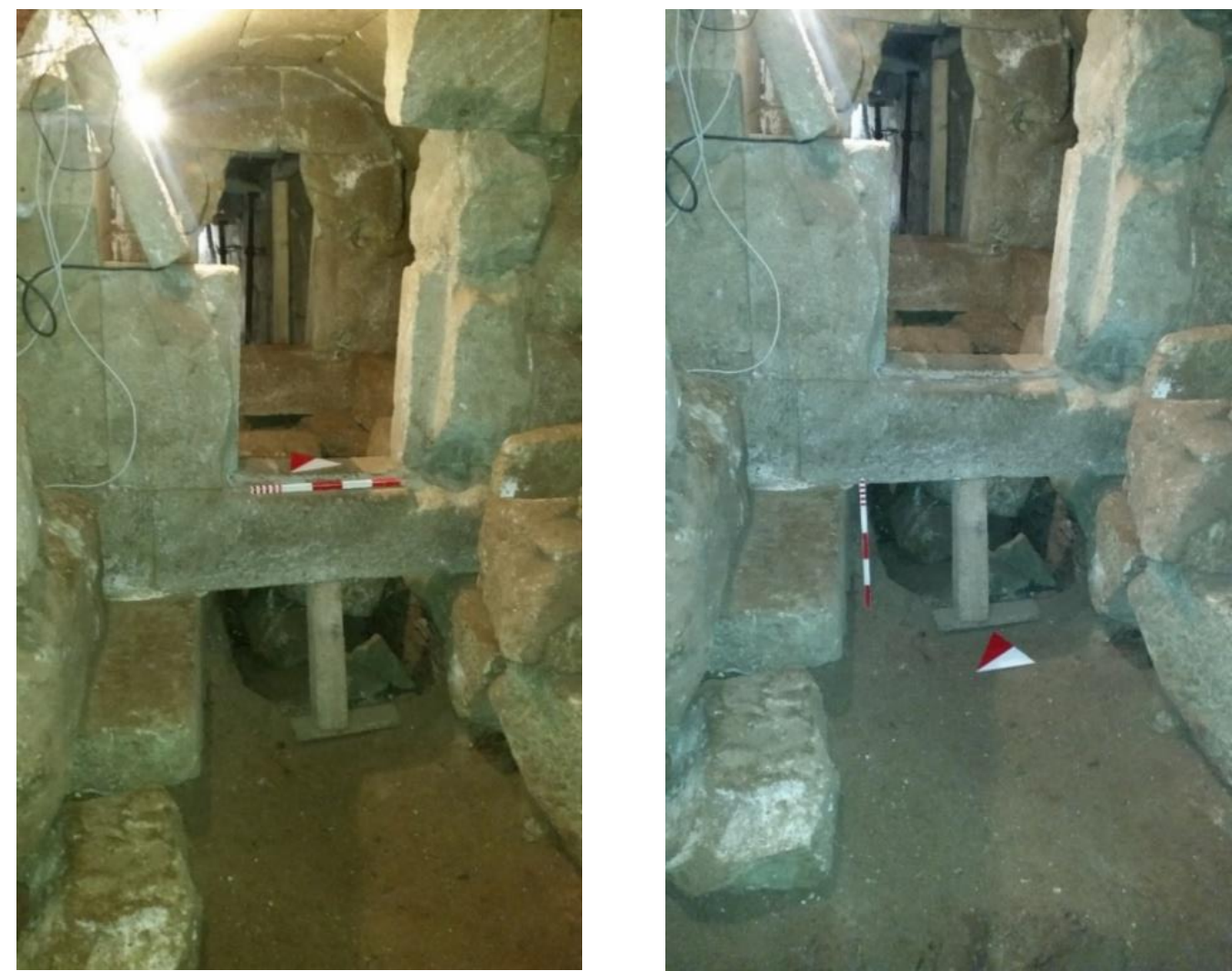

Görsel 10-11: Mezar Odası
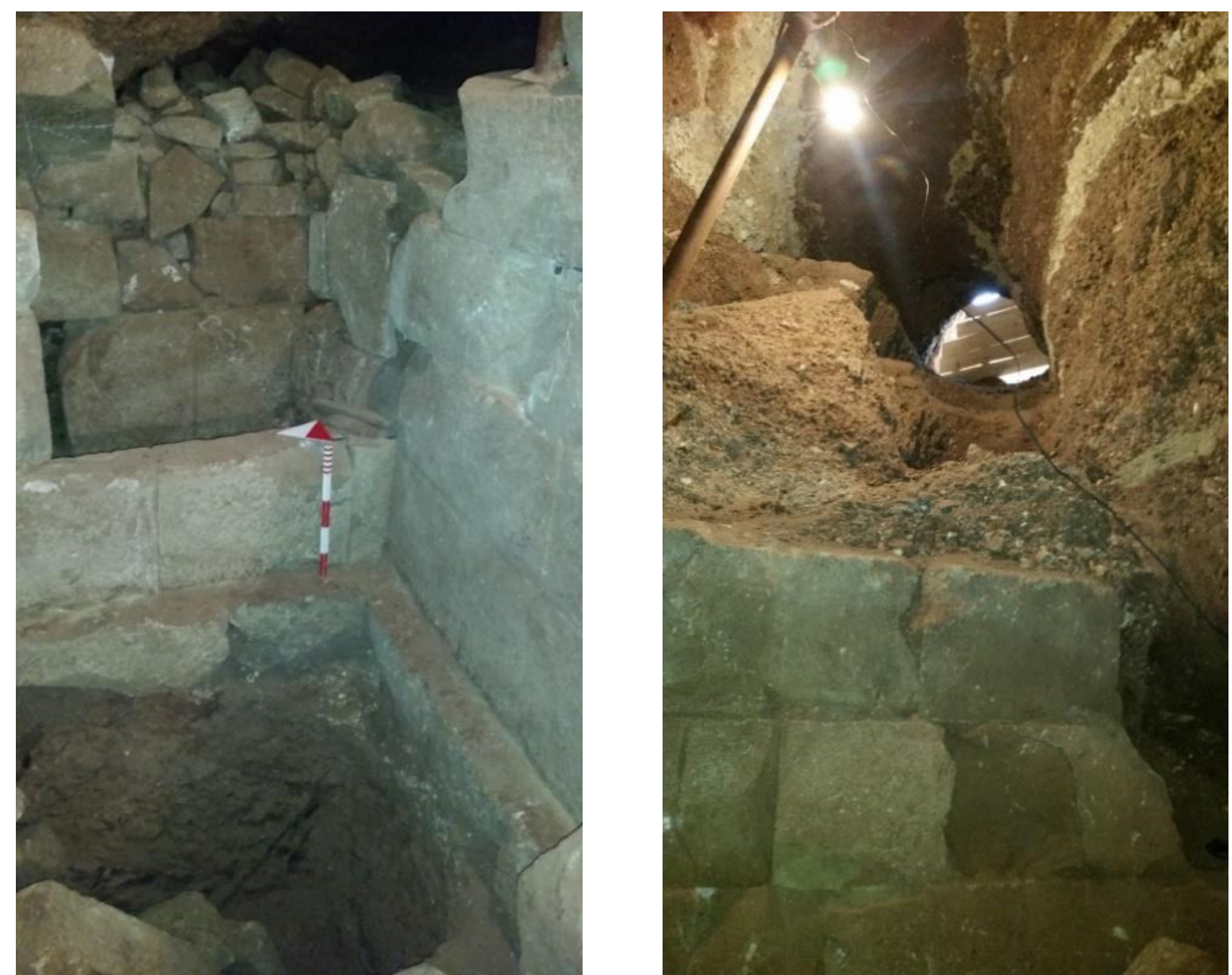

Görsel 12-13: Sunu Odası 
Yiğitpaşa, D., ve Temür, A., (2021). “Kavak Tepecik Tümülüsü Üzerine Gözlemler” ODUSOBİAD, 11(2),
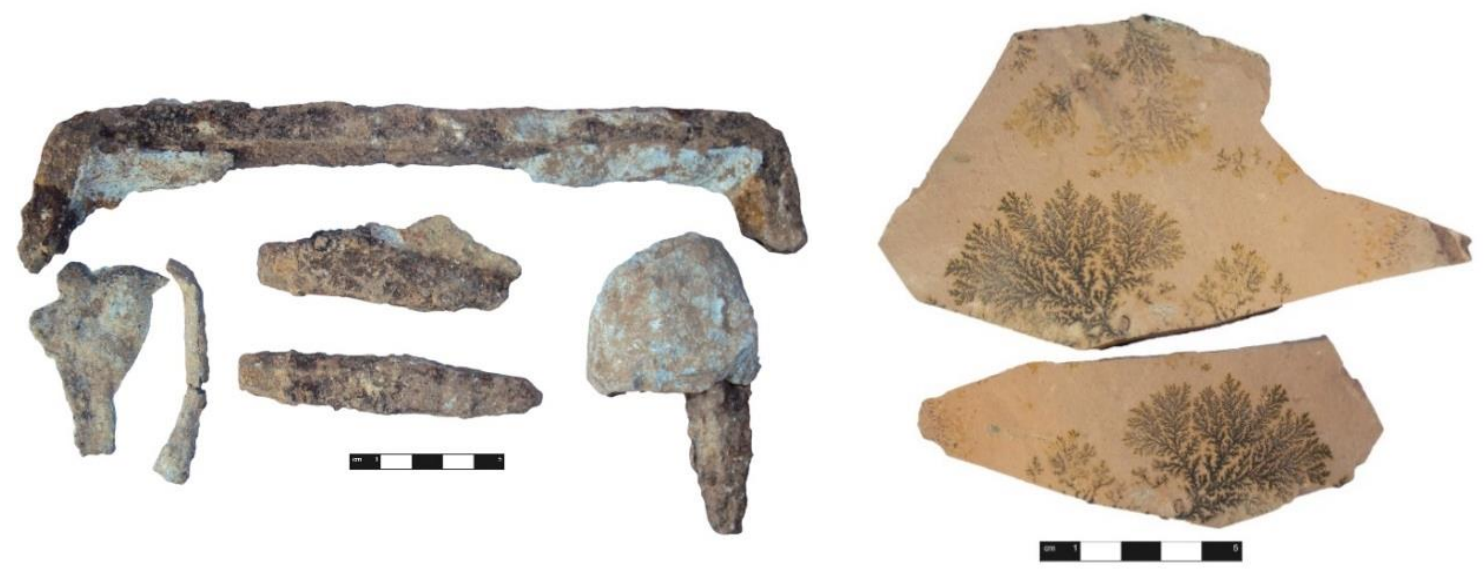

Görsel 14-15: Demir Kenet, Kurşun Parçaları ve Bitki Fosili Tortul Kayaç Parçaları
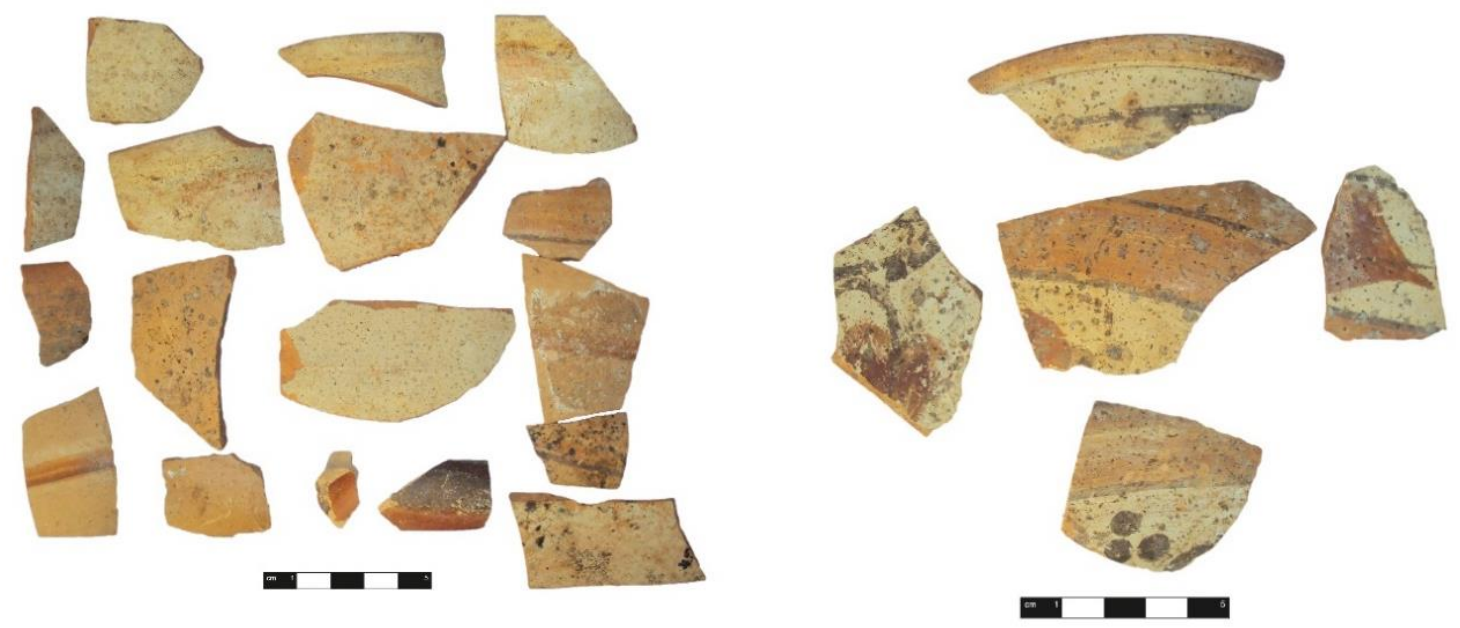

Görsel 16-17: Kahverengi Deve Tüyü Hamurlu Hellenistik Dönem Seramik Parçaları
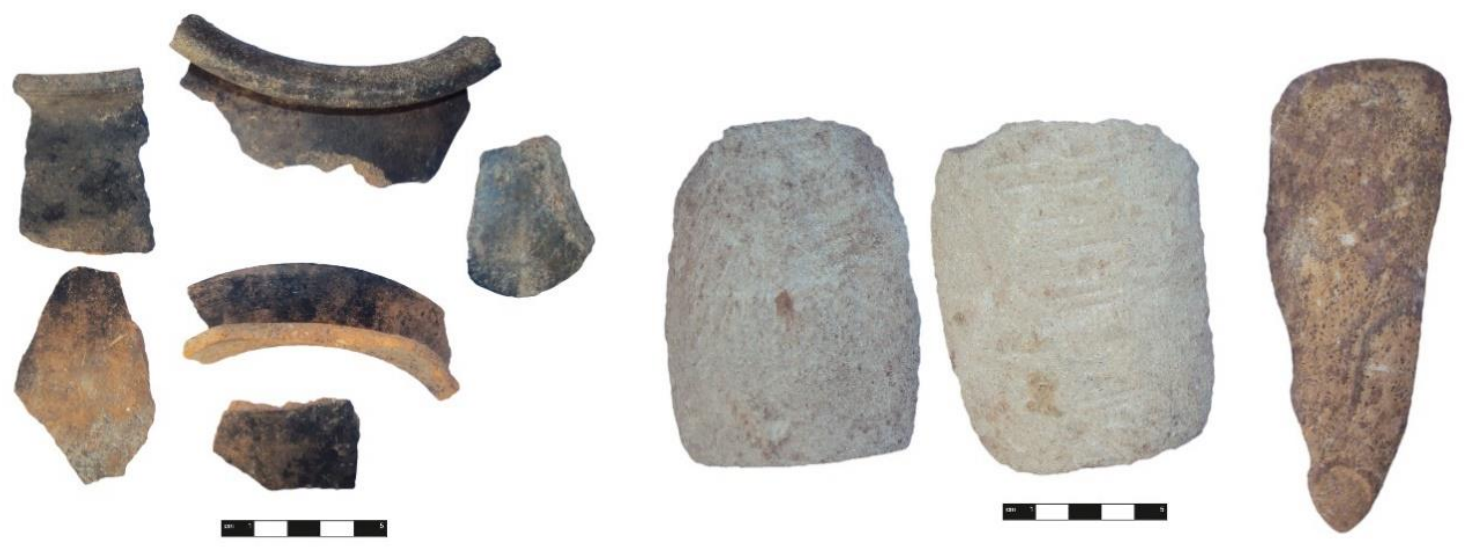

Görsel 18-19: Kahverengi Hamurlu Hellenistik Dönem Seramik Parçaları ve Taş Aletler 


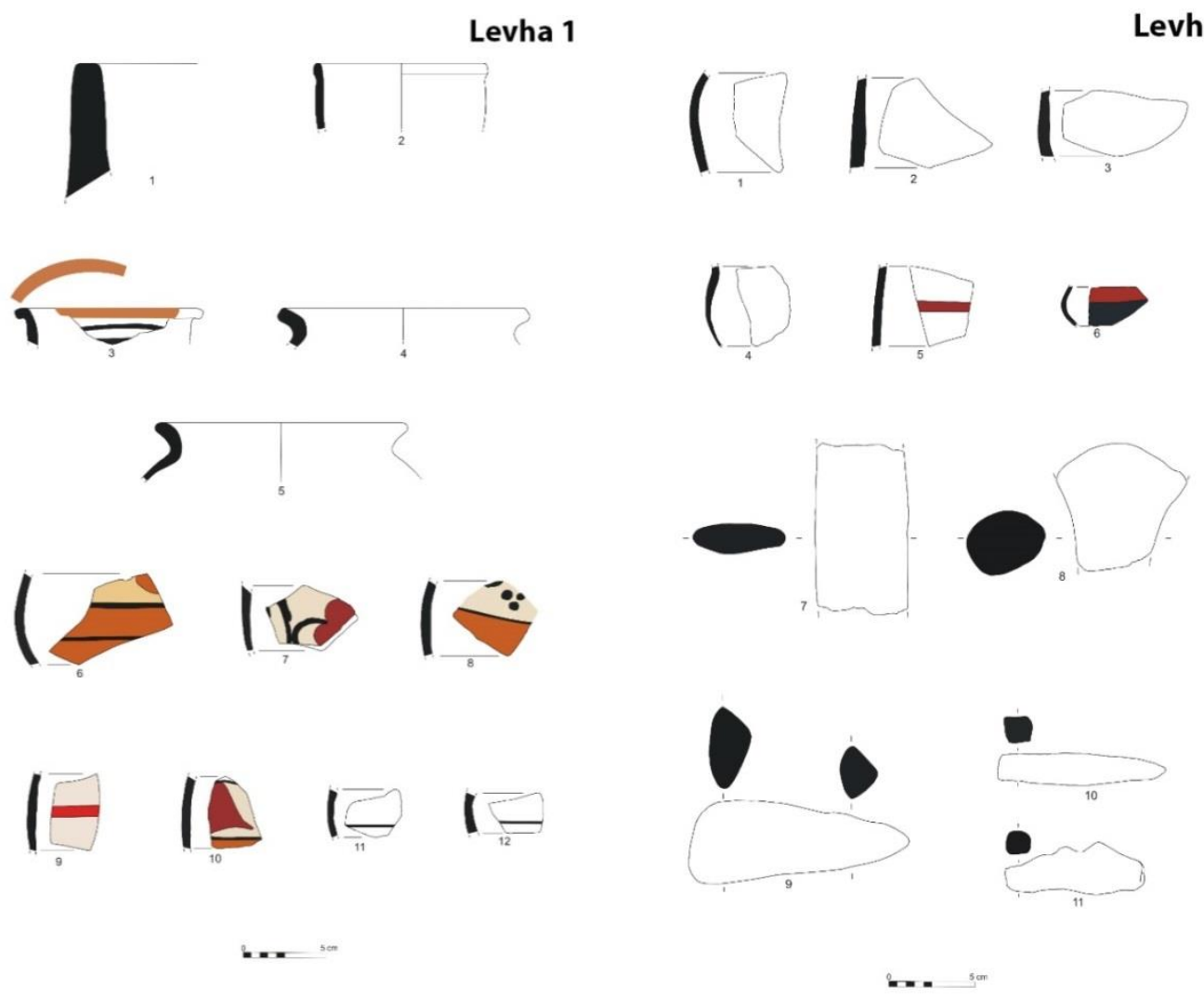

Görsel 20-21: Tümülüs'te Bulunan Seramikler ve Taş Aletler 
Yiğitpaşa, D., ve Temür, A., (2021). “Kavak Tepecik Tümülüsü Üzerine Gözlemler” ODUSOBİAD, 11(2), 466 - 451-466, doi: 10.48146/odusobiad.916029 